ISSN: 2302-8556

E-Jurnal Akuntansi Universitas Udayana

Vol.25.1.Oktober (2018): 434-463

DOI: https://doi.org/10.24843/EJA.2018.v25.i01.p17

\title{
Pengaruh Kualitas Audit Terhadap Manajemen Laba pada Perusahaan Perbankan yang Terdaftar di BEI Tahun 2013-2016
}

\author{
Ni Wayan Asri Mustika ${ }^{1}$ \\ Made Yenni Latrini ${ }^{2}$
}

${ }^{1}$ Fakultas Ekonomi dan Bisnis Universitas Udayana (Unud), Bali, Indonesia
email: nwasrimustika@ yahoo.com/Telp.082237759333
${ }^{2}$ Fakultas Ekonomi dan Bisnis Universitas Udayana (Unud), Bali, Indonesia

\begin{abstract}
ABSTRAK
Praktik manajemenlabapernahterjadi pada Enron Corp. Manajemen laba didefinisikan sebagai Praktik manajemen laba pernah terjadi pada Enron Corp. Manajemen laba didefinisikan sebagai perbedaan antara pendapatan yang direalisasi dari transaksi yang terjadi selama satu periode dengan biaya yang berkaitan dengan pendapatan tersebut. Tujuan penelitian ini adalah untuk menguji pengaruh kualitas audit terhadap manajemen laba. Kualitas audit pada penelitian ini diukur dengan ukuran Kantor Akuntan Publik (KAP), auditor spesialisasi industri, dan independensi auditor. Penelitian ini menggunakan data sekunder laporan keuangan perusahaan perbankan yang terdaftar di Bursa Efek Indonesia pada tahun 2013-2016. Penelitian ini menggunakan purposive sampling, dengan 64 sampel perusahaan perbankan. Metode analisis data yang digunakan dalam penelitian ini adalah uji regresi linier berganda. Hasil penelitian menunjukkan bahwa ukuran KAP tidak berpengaruh terhadap manajemen laba. Sedangkan, auditor spesialis industri dan independensi auditor berpengaruh terhadap manajemen laba.
\end{abstract}

Kata kunci: kualitas audit, ukuran KAP, auditor spesialisasi industri.

\begin{abstract}
Earnings management practices have occurred with Enron Corp. Profit management is defined as the difference between the realized revenues from transactions occurring during one period and the costs associated with the income. The purpose of this study is to examine the effect of audit quality on earnings management. The audit quality in this study is measured by the size of the Public Accounting Firm (KAP), the auditor of industry specialization, and the independence of auditors. This study uses secondary data of financial statements of banking companies listed on the Indonesia Stock Exchange in 2013-2016. This study uses purposive sampling, with 64 samples of banking companies. Data analysis method used in this research is multiple linear regression test. The results showed that the size of KAP does not affect the earnings management. Meanwhile, industry specialist auditor and auditor independence have an effect on earnings management.
\end{abstract}

Keywords: Audit quality, KAP measures, industry specialization auditors.

\section{PENDAHULUAN}

Scott (2003:369) mendefinisikan manajemen laba sebagai pilihan kebijakan akuntansi oleh manajer untuk mencapai sasaran secara objektif. Scott (2003: 369) membagi cara pemahaman atas manajemen laba menjadi dua, yaitusebagai perilaku 
oportunistik manajer dan sebagai efficient contracting (efficient earnings management). Manajemen laba sebagai perilaku oportunistik manajer dilakukan untuk memaksimumkan utilitas perusahaan dalam menghadapi kontrak kompensasi, kontrak utang, dan political cost (opportunistic earnings management). Manajemen laba dari perspektif efficient contracting (efficient earnings management) dapat dipahami sebagai cara untuk memberi manajer suatu fleksibilitas guna melindungi diri dan perusahaan dalam mengantisipasi kejadian-kejadian yang tak terduga.

Praktik manajemen laba pernah terjadi di luar negeri yaitu pada Enron Corp, Perusahaan terbesar ke tujuh di Amerika Serikat (AS) yang bergerak di bidang industri energi. Enron mengumumkan kebangkrutannya pada akhir tahun 2002. Bangkrutnya Enron dianggap bukan lagi semata-mata sebagai sebuah kegagalan bisnis, melainkan sebuah skandal yang multidimensional, yang melibatkan politisi dan pemimpin terkemuka di Amerika Serikat.

Penyebab kebangkrutan perusahaan Enron dicurigai telah melakukan praktek manajemen laba (window dressing) yaitu dengan cara penundaan pencatatan piutang karena kas digunakan untuk kepentingan pribadi. Dimana, para manajernya memanipulasi angka yang menjadi dasar untuk memperoleh kompensasi moneter yang besar (Boediono, 2005 dalam Indriani, 2010). Praktik kecurangan yang dilakukan antara lain yaitu di Divisi Pelayanan Energi, para eksekutif melebihlebihkan nilai kontrak yang dihasilkan dari estimasi internal. Pada proyek perdagangan luar negerinya misal di India dan Brasil, para eksekutif mencatat pembukuan laba yang mencurigakan. Strategi yang salah, investasi yang buruk dan 
ISSN: 2302-8556

E-Jurnal Akuntansi Universitas Udayana

Vol.25.1.Oktober (2018): 434-433

pengendalian keuangan yang lemah menimbulkan ketimpangan neraca yang sangat besar dan harga saham yang dilebih-lebihkan. Akibatnya, ribuanorang menjadi kehilangan pekerjaannya dan kerugian pasar milyaran dollar pada nilai pasar.

Ditambah dengan praktik akuntansi yang meragukan dan tidak independennya audit yang dilakukan oleh Kantor Akuntan Publik (KAP) Arthur Andersen terhadap Enron. Arthur Andersen, yang sebelumnya merupakan salah satu "The Big Six" tidak hanya melakukan manipulasi laporan keuangan Enron tetapi juga telah melakukan tindakan yang tidak etis dengan menghancurkan dokumen-dokumen penting yang berkaitan dengan kasus Enron.

Di Indonesia juga pernah terjadi praktik manajemen laba pada perusahaan perbankan, yaitu kasus Bank Century pada tahun 2009. Diketahui bahwa pemilik dan penjabat Bank Century melakukan penyalahgunaan dana nasabah. Pada 30 September 2009, laporan awal audit Badan Pemeriksa Keuangan terhadap Bank Century sebanyak 8 halaman yang telah beredar luas di masyarakat. Laporan tersebut mengungkapkan banyak kelemahan dan kejanggalan serius di balik penyelamatkan Bank Century dan ada dugaan pelanggaran kebijakan dalam memberikan bantuan kepada Bank Century. Akhirnya pada November 2009, 139 anggota DPR dan 8 Fraksi mengusulkan hak angket atas pengusutan kasus Bank Century. Hingga saat ini Bank Century telah berganti nama menjadi Bank Mutiara. Dalam proses hukum, pemilik dan para penjabat Bank century telah ditetapkan sebagai terdakwa kasus penggelapan dana nasabah. 
Praktik-praktik manajemen laba dapat mempengaruhi relevansi penyajian laporan keuangan sehingga laporan keuangan menjadi menyesatkan para penggunanya, yang seharusnya dapat membantu penggunanya dalam mengambil keputusan kedepannya. Hal ini mengakibatkan laporan keuangan tidak dapat dikatakan handal, karena informasi yang terkandung di dalam laporan keuangan tersebut tidak mengungkapkan informasi atau keadaan yang sesungguhnya. Dengan adanya praktik manajemen laba, mengakibatkan kualitas laporan keuangan menjadi kurang bagus. Untuk itu audit yang berkualitas mampu membatasi praktik manajemen laba sehingga dapat menyajikan laporan keuangan yang dapat dipertanggungjawabkan.

Pemeriksaan laporan keuangan yang dilakukan oleh auditor memiliki kualitas yang berbeda-beda. Oleh karena itu, auditing yang berkualitas tinggi (high-quality auditing) bertindak sebagai pencegah manajemen laba yang efektif, karena reputasi manajemen akan hancur dan nilai perusahaan akan turun apabila pelaporan yang salah ini terdeteksi dan terungkap (Indriani, 2010). Kualitas audit diprosikan menjadi tiga variabel yaitu, ukuran KAP, auditor spesialis industri dan independensi auditor.

Ukuran KAP dapat dibedakan menjadi KAP Big Four dan KAP Non Big Four. KAP Big Four dianggapmemiliki keahlian dan reputasi yang tinggi dibandingkan dengan KAP Non-Big Four. Menurut SA Seksi 210 dalam PSA No. 04 tentang pelatihan dan keahlian auditor independen disebutkan bahwa dalam melaksanakan audit untuk sampai pada pernyataan pendapat, auditor harus senantiasa 
ISSN: 2302-8556

E-Jurnal Akuntansi Universitas Udayana

Vol.25.1.Oktober (2018): 434-433

bertindak sebagai seorang ahli bidang akuntansi dan bidang auditing. Keahlian yang dimiliki KAP Big Four yaitu auditor KAP Big Four dengan pendidikan, pelatihan dan pengalaman yang dimiliki menjadikan orang yang ahli dalam bidang akuntansi dan auditing serta memiliki kemampuan untuk menilai secara objektif sesuai dengan prinsip akuntansi yang berterima umum dalam melakukan audit dengan memberikan pendapatnya atas laporan keuangan sehingga laporan keuangan dapat dipertanggungjawabkan sehingga bisa mendeteksi kesalahan penyajian posisi keuangan yang dilakukan manajer. KAP Non-Big Four kurang memiliki pemahaman tentang akuntansi dan auditing sehingga kurang bisa mendeteksi praktik manajemen laba yang dilakukan manajer. Berdasarkan dari keahlian yang dimiliki KAP Big Four, maka KAP Big Four lebih tinggi dalam menghambat praktik manajemen laba dibandingkan KAP Non-Big Four lebih rendah dalam menghambat praktik manajemen laba. Hal itu sejalan dengan hasil penelitian yang dilakukan (Gerayli et al, 2011) yang menunjukkan bahwa auditor Big Four berpengaruh negatif pada manajemen laba. Dimana, auditor Big Fourmemiliki kemampuan lebih baik dalam menghambat manajemen laba dibandingkan dengan Non-Big Four.

Auditor spesialis industri mempunyai peran sebagai pemonitoring laporan keuangan karena pemegang saham lebih percaya pada informasi pada laporan keuangan dengan kualitas audit yang tinggi. Karena dalam hal mengaudit, auditor mungkin menjumpai masalah-masalah yang kompleks dan subjektif, yang secara potensial material berpengaruh terhadap laporan keuangan.Masalah-masalah seperti ini mungkin memerlukan ketrampilan atau pengetahuan khusus dan menurut 
pertimbangan auditor memerlukan pekerjaan spesialis untuk mendapatkan bukti audit yang kompeten (SA Seksi 336 dalam PSA No. 39 tentang penggunaan pekerjaan spesialis).Auditor spesialis industri memiliki informasi yang banyak, sehingga mempunyai kemampuan memeriksa laporan keuangan lebih terinci karena auditor spesialis tersebut mengetahui kondisi perusahaan dan sektor perusahaan yang diaudit terfokus hanya pada spesialis industrinya. Berbeda dengan non auditor spesialis industri yang kurang memiliki banyak informasi dan auditornya mengaudit tidak terfokus pada spesialis industrinya. Sehingga perusahaan yang diaudit oleh auditor spesialis industri lebih besar dalam mendeteksi manajemen laba yang dilakukan manajer dibandingkan dengan auditor yang bukan auditor spesialis industri yang lebih rentan tidak terdeteksinya praktik manajemen laba.

Independensi auditor merupakan suatu standar etika auditing mengenai moral dan perilaku yang harus dimiliki oleh KAP. Auditor yang independen mencerminkan sikap mental yang tidak mudahnya dipengaruhi, tidak dikendalikan pihak lain, dan tidak tergantung pada orang lain. Menurut SA Seksi 200 dalam PSA No. 04 tentang standar umum independensi mengatakan bahwa audit harus dilaksanakan oleh seorang atau lebih yang memiliki keahlian dan pelatihan teknis sebagai auditor. Karakteristik yang dimiliki auditor independen adalah bersikap objektif, netral, menjaga sikap profesionalisme dan menjaga integritas. Independensi menuntut adanya kejujuran dalam diri auditor dalam mempertimbangkan fakta dan adanya pertimbangan yang objektif tidak memihak dalam diri auditor dalam merumuskan dan menyatakan pendapatnya. Auditor yang independen maka auditor tersebut 
ISSN: 2302-8556

E-Jurnal Akuntansi Universitas Udayana

Vol.25.1.Oktober (2018): 434-433

dengan sukarela akan melaporkan secara jujur tentang laporan posisi keuangan yang dibuat manajer dengan memberikan pendapatnya tanpa sedikitpun menutup-nutupi tentang kondisi keuangan yang terjadi sebenarnya di dalam perusahaan. Namun jika auditor tidak independen maka auditor tersebut akan melaporkan kondisi posisi keuangan yang menyesatkan karena melaporkan tidak sesuai dengan kondisi yang terjadi sebenarnya.Oleh karena itu, jika auditor independen mempunyai karakteristik tersebut maka kemungkinan untuk mendeteksi kesalahan-kesalahan penyajian laporan keuangan yang dilakukan manajer menjadi tinggi, tetapi jika auditor tersebut tidak independen maka dalam mendeteksi kesalahan-kesalahan penyajian laporan keuangan yang dilakukan oleh manajer menjadi rendah. Sehingga jika auditor tersebut independen maka lebih besar dalam menghambat manajemen laba. Namun jika auditor tersebut tidak independen maka lebih rendah dalam menghambat manajemen laba.

Manajemen laba umumnya dilakukan di perusahaan yang tingkat kesehatannya diukur dengan laba. Berbeda dengan di perusahaan perbankan yang mengukur tingkat kesehatannya dengan peraturan yang telah ditetapkan oleh Bank Sentral di suatu negara.Di Indonesia misalnya, yang merupakan Bank Sentral adalah Bank Indonesia. Namun, sejak 31 Desember 2013, Bank Indonesia (BI) melakukan serah terima pengalihan fungsi pengaturan dan pengawasan Bank kepada Otoritas Jasa Keuangan (OJK).Bank Indonesia berperan sebagai pengawas dalam aspek makroprudensial, sedangakan Otoritas Jasa Keuangan (OJK) berperan sebagai 
pengawas dalam aspek mikroprudensial. Sehingga, pengawasan perusahaan perbankan sekarang dilakukan oleh Otoritas Jasa Keuangan (OJK).

Tingkat kesehatan Bank di Indoensia telah diatur dalam Peraturan Otoritas Jasa Keuangan Nomor 4/POJK.02/2016 tentang Penilaian Kesehatan Bank Umum. Dalam Peraturan ini, dijelaskan bahwa Bank Umum di Indonesia wajib melakukan pemeriksaan Tingkat Kesehatan Bank setiap akhir semester, yakni pada akhir bulan Juni dan akhir bulan Desember. Serta pemriksaan juga dapat dilakukan sewaktuwaktu apabila diperlukan. Bank wajib melakukan penilaian Tingkat Kesehatan Bank secara individu dengan menggunakan pendekatan risiko (Risk-based Bank Rating), dengan cakupan penilaian terhadap faktor profil resiko (risk profile), Good Corporate Governance (GCG), rentabilitas (earnings), dan permodalan (capital).

Penelitian sebelumnya dilakukan oleh Indriani, (2010) meneliti tentang pengaruh kulitas auditor, Corporate Governance, leverage, dan kinerja keuangan terhadap manajemen laba. Objek dalam penelitian ini adalah perusahaan perbankan yang terdaftar di Bursa Efek Indonesia (BEI) pada tahun 2006-2008. Hasil dari penelitian ini menunjukan bahwa kualitas auditor, kepemilikan manajerial, kepemilikan institusional, dan CAR (Capital Adequacy Ratio) berpengaruh signifikan terhadap manajemen laba. Dimana, CAR adalah rasio kinerja bank untuk kecukupan modal yang dimiliki bank untuk menunjang aktiva yang mengandung atau menghasilkan risiko, misalnya kredit yang diberikan. Semakin tinggi CAR semakin baik kondisi sebuah bank. Perusahaan yang diaudit oleh auditor Big Four menunjukkan hasil yang positif antara kualitas auditor dengan praktik manajemen 
ISSN: 2302-8556

E-Jurnal Akuntansi Universitas Udayana

Vol.25.1.Oktober (2018): 434-433

laba. Semakin tinggi kepemilikan manajerial dan kepemilikan institusional, semakin rendah manajemen laba perusahaan tersebut. Semakin tinggi CAR juga semakin rendah manajemen laba perusahaan tersebut. Sedangkan, dewan komisaris independen dan leverage tidak memberikan pengaruh yang signifikan terhadap manajemen laba yang dilakukan perusahaan perbankan.

Luhgiatno, (2010) meneliti tentang analisis pengaruh kualitas audit terhadap manajemen laba studi pada perusahaan yang melakukan IPO di Indonesia. Objek dalam peneitian ini adalah perusahaan yang melakukan IPO di Indonesia. Hasil dari penelitian ini menunjukan bahwa KAP Big Four dan KAP spesialis industri terbukti tidak mampu membatasi praktik manajemen laba bagi perusahaan yang diauditnya pada saat perusahaan tersebut melakukan IPO di Indonesia.

Sanjaya, (2008) meneliti tentang auditor eksternal, komite audit terhadap manajemen laba. Penelitian ini dilakukan di perusahaan manufaktur yang terdaftar di Bursa Efek Jakarta periode 2001-2004. Studi ini menyimpulkan bahwa auditor berkualitas dan bereputasi yang ditunjukkan oleh Kantor Akuntan Publik yang berafiliasi dengan Big Four mampu mencegah dan mengurangi manajemen laba. Hasil penelitian auditor eksternal berpengaruh negatif signifikan terhadap manajemen laba

Gerayli et al, (2011) meneliti tentang impact of audit quality on earning management: evidence from Iran. Objek dari penlitian ini adalah seluruh perusahaan yang sudah listing di Bursa Efek Teheran, Iran. Gerayli, (2011) menggunakan variabel independen yaitu ukuran KAP, auditor spesialis industri, dan independensi 
auditor sebagai ukuran dari kualitas audit serta menggunakan empat variable kontrol yaitu ukuran perusahaan, arus kas operasi, prospek pertumbuhan, dan leverage. Hasil dari penelitian ini menunjukan bahwa kualitas audit berhubungan negatif signfikan terhadapa manajemen laba.

Herusetya, (2012) meneliti tentang analisa kualitas audit terhadap manajemen laba akuntansi dengan menggunakan pendekatan corporate measure versusconventional measure. Objek dari penlitian ini menggunakan sampel 1.152 tahunperusahaan dari perusahaan terdaftar non-keuangan di Bursa Efek Indonesia (BEI) untuk data panel tahun 1999-2007. Hasil dari penelitin ini menemukan adanya pengaruh negatif kualitas audit terhadap perilaku manajemen laba akrual yang diukur dengan akrual diskresioner absolut. Serta, hasil penelitian juga menemukan bahwa, walaupun KAP memiliki tingkat ketergantungan ekonomi terhadap klien, namun KAP tetap dapat menjaga reputasinya (reputation protection), terbukti dengan adanya pengaruh negatif ketergantungan ekonomi (client importance) terhadap akrual diskresioner absolut.

Rachmawati, (2013) meneliti tentang pengaruh kualitas auditor terhadap manajemen laba. Objek pada penelitian ini adalah perusahaan non keuangan yang terdaftar di Bursa Efek Indonesia (BEI) tahun 2009-2011. Hasil dari penelitian ini menunjukan bahwa auditor spesialis industri memberikan pengaruh yang signifikan terhadap manajemen laba. Hal ini berarti bahwa discretionary accruals perusahaan yang diaudit oleh auditor spesialis industri lebih rendah dibandingkan dengan discretionary accruals perusahaan yang diaudit oleh auditor non spesialis industri. 
ISSN: 2302-8556

E-Jurnal Akuntansi Universitas Udayana

Vol.25.1.Oktober (2018): 434-433

Sedangkan auditor big four tidak memberikan pengaruh yang signifikan terhadap manajemen laba.

Christiani, (2014) meneliti tentang pengarh kualitas audit terhadap manajemen laba. Objek dari penelitian ini adalah seluruh perusahaan publik yang terdaftar di Bursa Efek Indonesia (BEI) pada tahun 2010-2011. Hasil dari penelitian ini menunjukan bahwa ukuran KAP tidak berpengaruh terhadap manajemen laba, sedangkan spesialis industri auditor berpengaruh negatif terhadap manajemen laba.

Sari, (2016) meneliti tentang pengaruh kualitas audit terhadap manajemen laba pada perusahaan manufaktur. Objek dari penelitian ini adalah seluruh perusahaan manufaktur yang terdaftar di Bursa Efek Indonesia (BEI) pada tahun 2011-2013. Hasil dari penelitian ini menunjukkan bahwa dari tujuan model yang digunakan dalam penelitian terdapat tiga model yang berpengaruh signifikan terhadap manajemen laba yaitu ukuran KAP, spesialisasi industri, serta masa penugasan audit, sedangkan variabel client important, kesediaan pelaporan opini audit, ukuran perusahaan serta leverage tidak menunjukkan pengaruh signifikan terhadap manajemen laba.

De Angelo, (1981) dalam Indriani, (2010) yang berpendapat bahwa auditor yang berasal dari Big Four memberikan kualitas yang lebih baik dibandingkan auditor Non-Big Four. Penggunaan auditor berkualitas tinggi dapat mencegah emiten berlaku curang dalam menyajikan suatu laporan keuangan yang tidak relevan ke masyarakat. 
KAP Big Four memiliki keahlian dan reputasi yang tinggi dibandingkan dengan KAP Non-Big Four. Menurut SA Seksi 210 dalam PSA No. 04 tentang pelatihan dan keahlian auditor independen disebutkan bahwa dalam melaksanakan audit untuk sampai pada pernyataan pendapat, auditor harus senantiasa bertindak sebagai seorang ahli bidang akuntansi dan bidang auditing. Keahlian yang dimiliki KAP Big Four yaitu auditor KAP Big Four dengan pendidikan, pelatihan dan pengalaman yang dimiliki menjadikan orang yang ahli dalam bidang akuntansi dan auditing serta memiliki kemampuan untuk menilai secara objektif sesuai dengan prinsip akuntansi yang berterima umum dalam melakukan audit dengan memberikan pendapatnya atas laporan keuangan sehingga laporan keuangan dapat dipertanggungjawabkan sehingga bisa mendeteksi kesalahan penyajian posisi keuangan yang dilakukan manajer. KAP Non-Big Four kurang memiliki pemahaman tentang akuntansi dan auditing sehingga kurang bisa mendeteksi praktik manajemen laba yang dilakukan manajer. Berdasarkan dari keahlian yang dimiliki KAP Big Four, maka KAP Big Four lebih tinggi dalam menghambat praktik manajemen laba dibandingkan KAP Non-Big Four lebih rendah dalam menghambat praktik manajemen laba. Hal itu sejalan dengan hasil penelitian yang dilakukan (Becker et al, 1998; Francis et al, 1999; Krishnan, 2003 dalam Gerayli et al, 2011) yang menunjukkan bahwa auditor Big Four berpengaruh negatif pada manajemen laba. Dimana, auditor Big Fourmemiliki kemampuan lebih baik dalam menghambat manajemen laba dibandingkan dengan Non-Big Four. 
ISSN: 2302-8556

E-Jurnal Akuntansi Universitas Udayana

Vol.25.1.Oktober (2018): 434-433

Reputasi yang dimiliki oleh KAP Big Four yaitu auditor KAP Big Four akan berusaha sungguh-sungguh dalam mempertahankan pangsa pasar, kepercayaan masyarakat, dan reputasinya dengan cara memberi perlindungan kepada publik. Bentuk perlindungan kepada publik berupa opini atas laporan keuangan yang tidak menyesatkan sehingga tidak mengelabuhi investornya. Praktik manajemen laba dapat menyebabkan pengungkapan informasi laporan laba tidak mencerminkan keadaan yang sebenarnya dan menyebabkan pemakai laporan keuangan tidak memperoleh informasi yang akurat untuk dijadikan acuan dalam pengambilan keputusan sehingga laporan laba yang mengandung praktek manajemen laba dapat menyesatkan investor dalam mengestimasi return yang diharapkan. Jika auditor ini tidak dapat mempertahankan reputasinya, maka akan menimbulkan skeptisisme masyarakat terhadap kemampuan auditor dalam mendeteksi adanya praktik manajemen laba (Sanjaya, 2008). Artinya masyarakat akan ragu-ragu terhadap kemampuan auditor dalam mengaudit suatu laporan keuangan sehingga masyarakat menjadi tidak percaya terhadap opini yang diberikan.

KAP yang bereputasi maka KAP tersebut akan berusaha menjaga nama baiknya dengan memberikan informasi penyajian laporan keuangan yang tidak menyesatkan para investornya sehingga praktik manajemen laba yang dilakukan manajer bisa terdeteksi. Oleh karena itu, KAP yang bereputasi, lebih tinggi dalam menghambat manajemen laba yang dilakukan manajer dibandingkan KAP yang tidak bereputasi.

$\mathrm{H}_{1}$ : Ukuran KAP berpengaruh negatif terhadap manajemen laba. 
Teori agensi mengasumsikan bahwa manusia itu selalu self interest maka diperlukan pihak ketiga yang independen yang menjadi mediator antara pemegang saham dan agen, dalam hal ini auditor. Untuk mengatasi agency problem maka dalam hubungan keagenan diperlukan auditor yang berkredibilitas yang benar-benar mengetahui kondisi perusahaan yaitu auditor spesialis industri. Oleh sebab itu, auditor spesialis industri mempunyai peran sebagai pemonitoring laporan keuangan karena pemegang saham lebih percaya pada informasi pada laporan keuangan dengan kualitas audit yang tinggi. Karena dalam hal mengaudit, auditor mungkin menjumpai masalah-masalah yang kompleks dan subjektif, yang secara potensial material berpengaruh terhadap laporan keuangan.

Masalah-masalah seperti ini mungkin memerlukan ketrampilan atau pengetahuan khusus dan menurut pertimbangan auditor memerlukan pekerjaan spesialis untuk mendapatkan bukti audit yang kompeten (SA Seksi 336 dalam PSA No. 39 tentang penggunaan pekerjaan spesialis).

Owhoso et al, (2002) dalam Herusetya, (2009) menyatakan bahwa auditor dengan spesialisasi industri akan lebih dapat mendeteksi kesalahan dalam spesialisasi industrinya daripada diluar industrinya. Dengan demikian, karakteristik auditor spesialis industri adalah memiliki informasi yang lebih banyak berdasarkan pengalaman dalam mengaudit banyak klien pada spesialis industrinya, sehingga auditor spesialis industri mampu mendeteksi kekeliruan dan penyimpangan yang terjadi pada laporan keuangan.Hasil dari penelitin ini menemukan adanya pengaruh 
ISSN: 2302-8556

E-Jurnal Akuntansi Universitas Udayana

Vol.25.1.Oktober (2018): 434-433

negatif kualitas audit terhadap perilaku manajemen laba akrual yang diukur dengan akrual diskresioner absolut.

Auditor spesialis industri memiliki informasi yang banyak, sehingga mempunyai kemampuan memeriksa laporan keuangan lebih terinci karena auditor spesialis tersebut mengetahui kondisi perusahaan dan sektor perusahaan yang diaudit terfokus hanya pada spesialis industrinya. Berbeda dengan non auditor spesialis industri yang kurang memiliki banyak informasi dan auditornya mengaudit tidak terfokus pada spesialis industrinya. Sehingga perusahaan yang diaudit oleh auditor spesialis industri lebih besar dalam mendeteksi manajemen laba yang dilakukan manajer dibandingkan dengan auditor yang bukan auditor spesialis industri yang lebih rentan tidak terdeteksinya praktik manajemen laba.

$\mathrm{H}_{2}$ : Auditor spesialis industri berpengaruh negatif terhadap manajemen laba.

Independensi auditor merupakan suatu standar etika auditing mengenai moral dan perilaku yang harus dimiliki oleh KAP. Dalam teori agensi antara manajemen dan pemegang saham mempunyai kepentingan yang berbeda (Jensen dan Meckling, 1976 dalam Sunarto, 2009). Pemegang saham menginginkan keuntungan dari investasinya dan agen menginginkan balas jasa dari pekerjaan yang diberikan oleh pemegang saham. Oleh karena itu, untuk menjembatani perbedaan kepentingan diperlukan pengawasan terhadap laporan keuangan oleh auditor yang bebas dari pengaruh kepentingan pihak-pihak lain sehingga dibutuhkan independensi auditor. Peran independensi auditor yaitu untuk mengurangi tindakan oportunistik yang 
dilakukan pihak manajer yang dapat dilakukan melalui manipulasi pada angka-angka pada laporan keuangan perusahaan.

Independensi menuntut adanya kemandirian dalam mengaudit suatu laporan keuangan, tidak memihak kepada salah satu pihak, baik pihak prinsipal maupun pihak agen. Dengan kata lain, dalam independensi auditor, auditor tersebut harus bersikap netral. Auditor yang independen mencerminkan sikap mental yang tidak mudahnya dipengaruhi, tidak dikendalikan pihak lain, dan tidak tergantung pada orang lain. Menurut SA Seksi 200 dalam PSA No. 04 tentang standar umum independensi mengatakan bahwa audit harus dilaksanakan oleh seorang atau lebih yang memiliki keahlian dan pelatihan teknis sebagai auditor.

Karakteristik yang dimiliki auditor independen adalah bersikap objektif, netral, menjaga sikap profesionalisme dan menjaga integritas. Independensi menuntut adanya kejujuran dalam diri auditor dalam mempertimbangkan fakta dan adanya pertimbangan yang objektif tidak memihak dalam diri auditor dalam merumuskan dan menyatakan pendapatnya. Auditor yang independen maka auditor tersebut dengan sukarela akan melaporkan secara jujur tentang laporan posisi keuangan yang dibuat manajer dengan memberikan pendapatnya tanpa sedikitpun menutup-nutupi tentang kondisi keuangan yang terjadi sebenarnya di dalam perusahaan. Namun jika auditor tidak independen maka auditor tersebut akan melaporkan kondisi posisi keuangan yang menyesatkan karena melaporkan tidak sesuai dengan kondisi yang terjadi sebenarnya. 
ISSN: 2302-8556

E-Jurnal Akuntansi Universitas Udayana

Vol.25.1.Oktober (2018): 434-433

Oleh karena itu, jika auditor independen mempunyai karakteristik tersebut maka kemungkinan untuk mendeteksi kesalahan-kesalahan penyajian laporan keuangan yang dilakukan manajer menjadi tinggi, tetapi jika auditor tersebut tidak independen maka dalam mendeteksi kesalahan-kesalahan penyajian laporan keuangan yang dilakukan oleh manajer menjadi rendah. Sehingga jika auditor tersebut independen maka lebih besar dalam menghambat manajemen laba. Namun jika auditor tersebut tidak independen maka lebih rendah dalam menghambat manajemen laba.

Sejalan dengan studi yang dilakukan Meutia, (2004) yang meneliti tentang pengaruh independensi auditor terhadap manajemen laba untuk KAP Big 5 dan Non Big 5, menemukan bahwa non audit services berpengaruh negatif terhadap hubungan antara kualitas audit dengan manajemen laba melalui meningkatnya absolute discretionary accruals pada tahun perusahaan yang menerima non audit services. Selain itu berkaitan dengan masa jabatan auditor, hasil temuan ini menyokong pendapat yang menyatakan bahwa semakin lama masa jabatan auditor akan lebih meningkatkan kualitas audit karena memberikan kesempatan pada auditor untuk lebih mengenali transaksi kliennya. Walaupun tidak terdapat kesimpulan yang sama dari penelitian-penelitian tersebut, namun terdapat kesepakatan bahwa faktor yang dapat mengganggu independensi auditor diantaranya bayaran audit, adanya non-audit services, ukuran KAP dan lama jabatan sebagai auditor.

$\mathrm{H}_{3}$ : Independensi auditor berpengaruh negatif terhadap manajemen laba. 


\section{METODE PENELITIAN}

Lokasi penelitian ini adalah seluruh perusahaan perbankan yang terdaftar di Bursa Efek Indonesia (BEI) yang dapat diakses melalui www.idx.co.id. Obyek dari penelitian ini adalah manajemen laba yang dipegaruhi oleh kualitas audit (ukuran KAP, auditor spesialis industri, dan independensi auditor). Variabel bebas dalam penelitian ini adalah ukuran $\mathrm{KAP}\left(\mathrm{X}_{1}\right)$, auditor spesialis industri $\left(\mathrm{X}_{2}\right)$, independensi auditor $\left(\mathrm{X}_{3}\right)$.Variabel terikat dalam penelitian ini adalah manajemen laba $(\mathrm{Y})$.

Populasi dalam penelitian ini adalah seluruh perusahaan-perusahaan sektor perbankan yang sudah listing di Bursa Efek Indonesia (BEI) yang dimuat dalam IDX tahun 2013-2016.Sampel dalam penelitian ini, adalah laporan keuangan perusahaan perbankan tahun 2013-2016 yang terdafatar di Bursa Efek Indonesia (BEI).Penelitian ini dilakukan dengan menggunakan teknik purposive sampling method, yaitu penentuan sampel atas dasar kesesuaian karakteristik dan berdasarkan kriteria tertentu. Kriteria pemilihan sampel sebagai berikut: 1) Perusahaan Perbankan yang terdaftar di BEI tahun 2013-2016. 2) Perusahaan yang menerbitkan laporan keuangan yang telah diaudit untuk periode yang berakhir 31 Desember tahun 2013-2016. 3) Perusahaan perbankan listing di BEI selama 4 tahun berturut-turut dari tahun 2013 2016.

Pengumpulan data dilakukan dengan metode dokumentasi. Metode dokumentasi yaitu pengumpulan data dimana peneliti menyelidiki benda-benda tertulis seperti buku-buku, majalah, dokumen, peraturan-peraturan, dan sebagainya (Arikunto, 2002: 158). Metode dokumentasi ini dilakukan dengan cara 
ISSN: 2302-8556

E-Jurnal Akuntansi Universitas Udayana

Vol.25.1.Oktober (2018): 434-433

mengumpulkan laporan keuangan dan data lain yang diperlukan berdasarkan penjelasan sebelumnya. Data pendukung lainnya diperoleh dengan metode studi pustaka dari jurnal-jurnal ilmiah serta literatur yang memuat pembahasan berkaitan dengan penelitian ini.

Metode analisis yang digunakan yaitu dengan menggunakan model analisis regresi linear berganda dengan menggunakan software SPSS. Karena dalam analisis regresi, selain mengukur kekuatan hubungan antara dua variabel atau lebih, juga menunjukkan hubungan antara variabel dependen dengan variabel independen. Tahapan-tahapan metode analisis yang digunakan dalam penelitian ini adalah statistik deskriptif, uji asumsi klasik dan uji kelayakan model regresi.

\section{HASIL PENELITIAN DAN PEMBAHASAN}

Sampel pada penelitian ini adalah perusahaan perbankan yang terdaftar di Bursa Efek Indonesia (BEI) selama tahun 2013-2016. Penelitian ini menggunakan sampel yang memenuhi kriteria pemilihan sampel yang telah ditentukan sebelumnya. Berdasarkan hasil amatan yang sesuai dengan kriteria purposive sampling, maka terdapat 46 perusahaan perbankan, kemudian yang dapat dijadikan sampel adalah sebanyak 16 perusahaan dengan proses penyeleksian sebagai berikut: 


\section{Tabel 1.}

\section{Hasil Seleksi Pemilihan Sampel}

\begin{tabular}{rlc}
\hline & \multicolumn{1}{c}{ Keterangan } & $\begin{array}{c}\text { Jumlah } \\
\text { Perusahaan }\end{array}$ \\
\hline Populasi & $\begin{array}{l}\text { Perusahaan go public sektor perbankanyang terdaftar dalam Bursa } \\
\text { Kriteria: } 1\end{array}$ & $\begin{array}{l}\text { Efek Indonesia } \\
\text { Perusahaan Perbankan yang delisting selama periode 2012-2016 }\end{array}$ \\
$2 \quad \begin{array}{l}\text { Perusahaan Perbankan yang tidak menerbitkan laporan keuangan } \\
\text { yang telah diaudit untuk periode berakhir 31 Desember tahun } \\
\text { 2013-2016 }\end{array}$ & $(10)$ \\
$3 \quad \begin{array}{l}\text { Perusahaan dengan data laporan keuangan yang tidak lengkap } \\
\text { Total perusahaan yang dijadikan sampel }\end{array}$ & $(12)$ \\
Total sampel selama tahun 2012-2016 & 16 \\
\hline
\end{tabular}

Sumber:Data diolah, 2018

Statistik deskriptif berhubungan dengan pengumpulan dan peringkat data yang menggambarkan karakteristik sampel yang digunakan dalam penelitian ini. Hasil dari statistik deskriptif tersebut dapat dilihat pada Tabel2. berikut ini:

Tabel 2.

Hasil Statistik Deskriptif

\begin{tabular}{lrrrrr}
\hline & N & Minimum & Maksimum & \multicolumn{1}{c}{ Mean } & \multicolumn{1}{c}{$\begin{array}{c}\text { Std. } \\
\text { Deviation }\end{array}$} \\
\hline Y & 64 & 1,053 & 604,226 & 126,48919 & 172,938361 \\
Ukuran KAP & 64 & 0,00 & 1,00 & 0,7500 & 0,43644 \\
Auditor Spesialis & 64 & 0,00 & 1,00 & 0,4375 & 0,50000 \\
Industri & & & & & \\
Independensi Auditor & 64 & 0,00 & 1,00 & 0,3750 & 0,48795 \\
LnY & 64 & 0,052 & 6,404 & 3,52972 & 1,89475 \\
Valid N (listwise) & 64 & & & & \\
\hline
\end{tabular}

Sumber:Data diolah, 2018

Nilai minimum ukuran KAPadalah 0,00 dan nilai maksimum sebesar 1,00.

Mean atau nilai rata-rata ukuran KAP adalah 0,7500. Nilai rata-rata ukuran KAP lebih mendekati nilai maksimum. Hal ini berarti rata-rata ukuran KAP pada perusahaan perbankaan cenderung tinggi. Deviasi standar sebesar 0,43644, lebih kecil 
ISSN: 2302-8556

E-Jurnal Akuntansi Universitas Udayana

Vol.25.1.Oktober (2018): 434-433

dari pada nilai rata-rata. Artinya, ada fluktuasi yang rendah pada ukuran KAP diperusahaan perbankan.

Nilai minimum auditor spesialis industri adalah 0,00 dan nilai maksimum sebesar 1,00. Mean atau nilai rata-rata auditor spesialis industri adalah 0,4375. Nilai rata-rata auditor spesialis industri lebih mendekati nilai minimum. Hal ini berarti auditor spesialis industri perusahaan pada perusahaan perbankan cenderung rendah. Deviasi standar sebesar 0,50000, lebih besar dari pada nilai rata-rata. Artinya, ada fluktuasi yang tinggi pada auditor spesialis industri di perusahaan perbankan.

Nilai minimum independensi auditor adalah 0,00 dan nilai maksimum sebesar 1,00. Mean atau nilai rata-rata idependensi auditor adalah 0,3750 . Nilai rata-rata independensi auditorlebih mendekati nilai minimum. Hal ini berarti rata-rata independensi auditor pada perusahaan perbankan cenderung rendah. Deviasi standar sebesar 0,48795, lebih besar dari pada nilai rata-rata. Artinya, ada fluktuasi yang tinggi pada independensi auditor di perusahaan perbankan.

Nilai minimum manajemen laba adalah 0,052 dan nilai maksimumnya adalah 6,404. Mean atau rata-rata untuk manajemen laba adalah 3,52972. Mean manajemen laba bernilai positif, berarti rata-rata perusahaan perbankan cenderung tidak melakukan manajemen laba dengan pola menurunkan laba. Deviasi standar adalah 1,894750. Deviasi standar manajemen laba lebih rendah dari pada nilai rata-rata. Artinya, ada fluktuasi rendah pada manajemen laba perusahaan perbankan yang menjadi sampel. 
Penelitian ini menggunakan persamaan regresi linear berganda untuk mengetahui pengaruh ukuran KAP, auditor spesialis industri, dan independensi auditor pada manajemen laba. Rekapitulasi hasil analisis regresi linear berganda disajikan pada Tabel3.

Tabel 3.

Hasil Analisis Regresi Linier Berganda

\begin{tabular}{cccccc}
\hline Model & \multicolumn{7}{c}{ Unstandardized Coefficients } & \multicolumn{3}{c}{$\begin{array}{c}\text { Standardized } \\
\text { Coefficients }\end{array}$} & & \\
& B & Std. & Beta & t & Sig. \\
\hline (Constant) & 2,525 & 0,423 & & 5,975 & 0,000 \\
X1 & 2,097 & 0,504 & 0,483 & 4,164 & 0,000 \\
X2 & $-0,084$ & 0,441 & $-0,22$ & $-1,92$ & 0,849 \\
X3 & $-1,416$ & 0,393 & $-0,365$ & $-3,605$ & 0,001 \\
\hline Sumber: Data diolah, 2018 & & & &
\end{tabular}

Dari hasil analisis regresi linier berganda pada Tabel 3. dapat dibuat persamaan sebagai berikut.

$$
Y=2,525+2,097 X_{1}-0,084 X_{2}-1,416 X_{3}
$$

Berdasarkan persamaan di atas, dapat dijelaskan bahwa nilai konstanta sebesar 2,525 menunjukkan bahwa apabila ukuran KAP, auditor spesialis industri, dan independensi auditor adalah konstan atau memiliki varians nol, maka manajemen laba akan sebesar 2,525 persen atau terjadi manajemen laba dengan pola menaikan laba.

Nilai koefisien regresi ukuran KAP $\left(\mathrm{X}_{1}\right)$ sebesar 2,097 menunjukkan bahwa apabila nilai ukuran KAP meningkat sebesar satu persen, maka nilai Discretionary Accrual sebagai proksi manajemen laba akan mengalami peningkatan sebesar 2,097 persen dengan asumsi variabel lainnya konstan. 
ISSN: 2302-8556

E-Jurnal Akuntansi Universitas Udayana

Vol.25.1.Oktober (2018): 434-433

Nilai koefisien regresi auditor spesialis industri $\left(\mathrm{X}_{2}\right)$ sebesar -0,064 menunjukkan bahwa apabila nilai auditor spesialis industri meningkat sebesar satu persen, maka nilai Discretionary Accrual sebagai proksi manajemen laba akan mengalami penurunan sebesar -0,064 persen dengan asumsi variabel lainnya konstan.

Nilai koefisien regresi independensi auditor $\left(\mathrm{X}_{3}\right)$ sebesar -1,416 menunjukkan bahwa apabila independensi auditor meningkat sebesar satu persen, maka nilai Discretionary Accrual sebagai proksi manajemen laba akan mengalami penurunan sebesar -1,416 persen dengan asumsi variabel lainnya konstan.

Uji koefisien determinasi mengukur seberapa jauh kemampuan model dalam menerangkan variasi variabel dependen (Ghozali, 2016). Nilai koefisien diterminasi antara nol dan satu. Nilai Adjusted $\mathrm{R}^{2}$ yang kecil berarti kemampuan variabel-variabel independen dalam menjelaskan variasi variabel dependen amat terbatas. Nilai yang mendekati satu berarti variabel-variabel independen memberikan hampir semua informasi yang dibutuhkan untuk memprediksi variasi variabel dependen (Ghozali, 2016). Berikut ini adalah koefisien determinasi dari penelitian ini yang disajikan dalam Tabel 4.

Tabel 4.8

Hasil Koefisien Determinasi

\begin{tabular}{ccccc}
\hline Model & R & R Square & Adjusted R Square & $\begin{array}{c}\text { Std.Error of the } \\
\text { Estimate }\end{array}$ \\
\hline 1 & 0,637 & 0,406 & 0,376 & 1,496769 \\
\hline
\end{tabular}

Sumber: Data diolah, 2018 
Dari tabel 4. menunjukan bahwa nilai Adjusted $\mathrm{R}^{2}$ dalam penelitian inisebesar 0,406berarti bahwa 40,6\% (persen) varians manajemen laba disebabkan oleh perubahan dari variabel ukuran KAP, auditor spesialis industri, dan independensi auditor. Sedangkan sisanya yaitu sebesar 59,4\% (persen) dijelaksan oleh variabel lain di luar model.

Uji kelayakan model (Uji F) bertujuan untuk menguji apakah model yang digunakan dalam penelitian ini layak atau tidak untuk digunakan sebagai alat analisis dalam menguji pengaruh variabel independen pada variabel dependennya.

\section{Tabel 5.}

Hasil Uji Kelayakan Model (Uji F)

\begin{tabular}{cccccc}
\hline Model & $\begin{array}{c}\text { Sum of } \\
\text { Squares }\end{array}$ & Df & Mean Square & F & Sig. \\
\hline Regression & 91,756 & 3 & 30,585 & 13,652 & 0,000 \\
Residual & 134,419 & 60 & 2,240 & & \\
Total & 226,175 & 60 & & & \\
\hline Sumber:Data diolah, 2018 & & &
\end{tabular}

Adapun hasil uji F ditunjukkan pada Tabel 4.9 bahwa nilai uji F sebesar 13,652 denganp-value (Sig. F) 0,000 lebih kecil dari nilai $\alpha=0,05$. Hal ini menunjukkan bahwa model persamaan dalam penelitian ini layak untuk digunakan.

Uji statistik t dilakukan untuk mengetahui seberapa besar pengaruh variabel independen terhadap variabel dependen secara parsial. Uji statistik t dilakukan dengan membandingkan hasil nilai probabilitas ( $p$-value) tiap-tiap variabel dengan $\alpha$ $=0,05$ seperti ditunjukkan pada Tabel 6 . berikut: 
ISSN: 2302-8556

E-Jurnal Akuntansi Universitas Udayana

Vol.25.1.Oktober (2018): 434-433

Tabel 6.

Hasil Uji Hipotesis (Uji t)

\begin{tabular}{lrr}
\hline Model & $\mathbf{t}$ & Sig. \\
\hline (Constant) & 5,975 & 0,000 \\
Ukuran KAP & 4,164 & 0,000 \\
Auditor Spesialis Industri & $-1,92$ & 0,849 \\
Independensi Auditor & $-3,605$ & 0,001
\end{tabular}

Sumber:Data diolah, 2018

Berkdasarkan dari tabel 6. di atas, maka berikut ini dapat dijelaskan hasil pengujian hipotesis, yaitu nilai t hitung variabel ukuran KAP sebesar 4,164 dan nilai signifikansi uji t yakni $p$-value sebesar 0,000 lebih rendah dari $\alpha=0,05$ serta nilai koefisien regresi sebesar 0,483. Ini berarti bahwa ukuran KAP berpengaruh positif signifikan terhadap manajemen laba, sehingga hipotesis pertama $\left(\mathrm{H}_{1}\right)$ dalam penelitian ini ditolak.Hasil penelitian ini konsisten dengan Indriani (2010), Luhgiatno (2010), Rahmadika (2011), Rachmawati (2013) dan Christiani (2014), dalam penelitiannya menunjukan bahwa ukuran KAP tidak berpengaruh terhadap manajemen laba. Sehingga, ukuran KAP di anggap belum mampu membatasi pratik manajemen laba.

Nilai t hitung variabel auditor spesialis industri sebesar -0,192 dan nilai signifikansi uji t yakni $p$-value sebesar 0,849 lebih besar dari $\alpha=0,05$ serta nilai koefisien regresi sebesar -0,0022. Ini berarti bahwa auditor spesialis industri berpengaruh negatif namun tidak signifikan terhadap manajemen laba, sehingga hipotesis kedua $\left(\mathrm{H}_{2}\right)$ dalam penelitian ini diterima.Hasil penelitian ini konsisten dengan Gerayli et al. (2011), Herusetya (2012), Rachmawati (2013), Christiani (2014), dan Sari (2016), dalam penelitiannya menunjukan bahwa auditor spesialis 
industri berpengaruh terhadap manajemen laba. Sehingga, auditor spesilis industri di anggap mampu membatasi pratik manajemen laba, namun tidak signifikan.

Nilai t hitung variabel independensi auditor perusahaan sebesar -3,608 dan nilai signifikansi uji t yakni $p$-value sebesar 0,001 lebih kecil dari $\alpha=0,05$ serta nilai koefisien regresi sebesar -0,365. Ini berarti bahwa independensi auditor berpengaruh negatif signifikan terhadap manajemen laba, sehingga hipotesis ketiga $\left(\mathrm{H}_{3}\right)$ dalam penelitian ini diterima.Hasil penelitian ini konsisten dengan Gerayli et al. (2011), Herusetya (2012), dan Sari (2016), dalam penelitiannya menunjukan bahwa independensi auditor berpengaruh terhadap manajemen laba. Sehingga, independensi auditor di anggap mampu membatasi pratik manajemen laba.

\section{SIMPULAN}

Berdasarkan hasila nalisis dan pembahasan yang telah dipaparkan pada bab sebelumnya, didapatkan simpulan bahwa ukuran KAP berpengaruh positif pada manajemen laba. Praktik manajemen laba terjadi karena perusahaan memiliki keinginan agar kinerja keuangan perusahaan tampak bagus dimata calon investor. Dengan adanya keberadaan KAP Big Four bukan untuk mengurangi manajemen laba, tetapi lebih kepada peningkatan kredibilitas laporan keuangan dengan mengurangi gangguan yang ada didalamnya sehingga bisa menghasilkan laporan keuangan yang lebih handal. Sehingga KAP Big Four tidak mampu membatasi praktik manajemen laba. 
ISSN: 2302-8556

E-Jurnal Akuntansi Universitas Udayana

Vol.25.1.Oktober (2018): 434-433

Auditor spesialis industry berpengaruh negative pada manajemen laba. Auditor spesialis industri memiliki informasi yang banyak, sehingga mempunyai kemampuan memeriksa laporan keuangan lebih terinci karena auditor spesialis tersebut mengetahui kondisi perusahaan dan sektor perusahaan yang diaudit terfokus hanya pada spesialis industrinya.Namun hal tersebut tidak menjamin auditor spesialis industri dapat menghambat pratik manajemen laba.Lebih tepatnya untuk membatasi praktik manajemen laba, seorang auditor harus memiliki sikap skeptisme. Sehingga perusahaan yang diaudit oleh auditor spesialis industri dapat mendeteksi manajemen laba yang dilakukan oleh manajer namun tidak signifikan.

Independensi auditor berpengaruh negatif pada manajemen laba. Auditor yang independen merupakan auditor yang dengan suka rela akan melaporkan secara jujur tentang laporan posisi keuangan yang dibuat manajer dengan memberikan pendapatnya tanpa sedikitpun menutup-nutupi tentang kondisi keuangan yang terjadi sebenarnya di dalam perusahaan. Sehingga jika auditor tersebut independen maka lebih besar dalam menghambat manajemen laba. Namun jika auditor tersebut tidak independen makalebih rendah dalam menghambat manajemen laba.

Jadi dilihat dari nilai Rsquare, pengaruh kualitas audit yang diproksikan dengan ukuran KAP, auditor spesialis industri, dan independensi auditor terhadap manajemen laba sebesar 40,6 persen. Dan penelitian ini sudah signifikan dilihat dari hasil uji F. Sehingga korelasi atau hubungan dari model tersebut dapat digunakan sebagai alat prediksi. 
Berdasarkan dari pembahasan dan simpulan yang telah dipaparkan sebelumnya, maka saran yang dapat disampaikan oleh penelitibahwa dilihat dari nilai adjusted $R$ square inisebesar 0,406 berarti bahwa 40,6\% varians manajemen laba disebabkan oleh perubahan dari variable ukuran KAP, auditor spesialis industri, dan independensi auditor. Sedangkan sisanya yaitu sebesar 59,4\% dijelaksan oleh variabel lain di luar model. Penelitian selanjutnya yang meneliti perusahaan perbankan diharapkan untuk menguji faktor-faktor lain yang mungkin berpengaruh dengan praktik manajemen laba, biasanya dengan menambahkan variable independennya selain dalam penelitian ini atau mecari variabel lain sebagai varaibel moderating. Hal ini dimaksudkan agar memberikan wawasan dan pengetahuan yang semakin luas terhadap faktor-faktor yang berpengaruh terhadap adanya praktik manajemen laba

Bagi perusahaan perbankan di Indonesia mekenasime komite audit perusahaan lebih diperkuat agar dapat menghasilkan audit yang berkualitas untuk membatasi praktik manajemen laba. Karena komite audit juga mengambil peran dalam pengambilan keputusan dan pelaporan keuangan yang telah diaudit oleh audior eksternal.

Bagi investor sebaiknya lebih berhati-hati dalam mengambil keputusan berinvestasi, agar melihat audit tenure auditor yang mengaudit di perusahaan tersebut terlebih dahulu, karena dilihat dari independensi auditor yang tinggi dapat mengurangi manajemen laba. 


\section{REFERENSI}

Becker, C.L., Mark, L. DeFond, J.J. \& Subra-manyam, K.R. (1998), “The Effect of Audit Quality on Earnings Management”. Social Science Research Network, $1-24$.

DeAngelo. (1986). “Accounting Numbers as Market Valuation Substitutes: A Study of Manage-ment Buyouts of Public Shareholders." Thev Accounting Review, $61,400-420$.

Gerayli, M., Ma'atofa, S., \& Yane Sari, A.M. (2011). "Impact of Audit Quality On Earnings Management: Evidence from Iran". International Research Journal of Finance and Economics, Issue 66, pp. 77-84.

Ghozali, Imam. (2016). "Aplikasi Analisis Multivariate dengan Program IBM SPSS 23 ”, Semarang: Badan Penerbit Universitas Diponegoro.

Herusetya, A. (2009), "Efektifitas Pelaksanaan Cor-porate Governance dan Audit Eksternal-Auditor Dengan Spesialisasi Industri Dalam Menghambat Manajemen Laba”, Jurnal Akuntansi dan Auditing Indonesia, 13(2), 167-188.

Indriani, Yohana. (2010), "Pengaruh Kualitas Auditor, Corporate Governance dan Kinerja Keuangan Terhadap Manajemen Laba (Studi Pada Perusahaan Perbankan yang Terdaftar di Bursa Efek Indonesia (BEI) Tahun 2006-2008)”. Semarang: Skripsi JurusanAkuntansi Fakultas Ekonomika dan Bisnis Universitas Diponegoro.

Luhgiatno. (2010). “Analisis Pengaruh Kualitas Audit Terhadap Manajemen Laba (Studi Pada Perusahaan Yang Melakukan IPO di Indonesia)", Fokus Ekonomi, Vol. 5, No. 2.

Meutia, Inten. (2004), "Pengaruh Independensi Auditor Terhadap Manajemen Laba untuk KAP Big-5 dan Non Big-5”. Jurnal Riset Akuntansi Indonesia. 7(3), 333-350.

Republik Indonesia. 2016. Peraturan Otoritas Jasa Keuangan Nomor 4/POJK.02/2016 tentang Penilaian Kesehatan Bank Umum. Jakarta.

Rahmadika. (2011), "Pengaruh kualitas Auditor terhadap Manajemen Laba (Studi Epiris pada Perusahaan Manufaktur yang terdaftar di Bursa Efek Indonesia Tahun 2008-2009)”, Skripsi Universitas Diponegoro. 
Ni Wayan Asri Mustika dan Made Yenni Latrini. Pengaruh...

Sanjaya, I Putu Sugiartha. (2008), “Auditor Eksternal, Komite Audit, dan Manajemen Laba”, Jurnal Riset Akuntansi Indonesia. 11(1), 97-116.

Sari, Tri Wulan. (2016), "Pengaruh Kualitas Audit Terhadap Manajemen Laba pada Perusahaan Manufaktur", Jurnal Ilmu dan Riset Akuntansi,12(5), 2460-0585. 